Sains Malaysiana 49(3)(2020): 561-571

http://dx.doi.org/10.17576/jsm-2020-4903-11

\title{
Identification of Key Sensory Attributes of Sambal-Terasi, Impact of Different Type of Terasi, Chemical Characteristics and Salt Addition
}

(Pengenalpastian Sifat Sensori Utama Sambal Terasi, Impak Jenis Terasi Berbeza, Pencirian Kimia serta Penambahan Garam)

\author{
Mery Tambaria Damanik Ambarita*, Katleen Raes \& Bruno De Meulenaer
}

\section{ABSTRACT}

This research studied the identification of key sensory attributes of sambal-terasi as caused by the use of different types of terasi and by the chemical characteristics of terasies, including the addition of salt. Sambal-terasi is a chili sauce containing terasi, a fermented salty seafood from Indonesia. Six different types of terasi, with varying chemical characteristics, including proximate compositions, salt content, free amino acids, biogenic amines, and short chain fatty acids, were prepared as sambal-terasi (at 6\%, fresh weight of terasi). To five sambal-terasies table salt was added, aiming to reach a comparable salt content as the sambal-terasi with the highest salt content among the six mentioned sambal-terasies. Eighty-seven un-trained panelists assessed the sambal-terasies' acceptability in a hedonic test and nine trained panelists rated their intensities towards the attributes sweet, bitter, salty, sour, umami, fishy and rebon. The addition of different types of terasies significantly affected the sensory characteristics of sambal-terasies. The undesirable compounds formed during production of terasi (biogenic amines and short chain fatty acids) could still be perceived in sambal-terasi, therefore their presences should be controlled. Salty, umami and rebon were identified as desirable tastel flavor attributes which were enhanced by the addition of salt. Bitterness was identified as an undesirable taste attribute, which could be reduced by the addition of salt. A salt content of 2-2.5\% in sambal-terasi was tentatively proposed as a good compromise with respect to the sensorial aspects and salt intake.

Keywords: Salt; sambal-terasi; sensory analysis; taste; terasi

\section{ABSTRAK}

Kajian ini mengkaji pengenalpastian sifat sensori utama sambal-terasi yang disebabkan oleh penggunaan pelbagai jenis terasi dan ciri kimia terasi, termasuklah penambahan garam. Sambal-terasi adalah sos cili yang mengandungi terasi, makanan laut masin yang difermentasi dari Indonesia. Enam jenis terasi berbeza dengan pelbagai ciri kimia termasuk kandungan komposisi, kandungan garam, asid amino bebas, amina biogen serta asid lemak rantai pendek, disediakan sebagai sambal-terasi (pada 6\%, berat terasi segar). Lima garam meja sambal-terasi ditambahkan, bertujuan untuk mencapai kandungan garam yang sebanding dengan sambal-terasi dengan kandungan garam tertinggi antara enam sambal-terasi yang disebutkan. Lapan puluh tujuh panelis tidak terlatih menilai kesesuaian sambal-terasi dalam ujian hedonik dan sembilan ahli panel terlatih menilai keamatan mereka terhadap sifat manis, pahit, masin, masam, umami, hanyir dan rebon. Penambahan jenis terasi berbeza telah menjejaskan ciri sensori sambal-terasi. Sebatian yang tidak diingini yang dihasilkan semasa penghasilan terasi (amina biogen dan asid lemak rantai pendek) masih boleh dilihat dalam sambal-terasi, oleh itu kehadiran mereka harus dikawal. Masin, umami dan rebon telah dikenal pasti sebagai sifat rasa/perisa yang diingini yang dipertingkatkan dengan penambahan garam. Kepahitan telah dikenal pasti sebagai sifat rasa yang tidak diingini, yang boleh dikurangkan dengan penambahan garam. Kandungan garam sebanyak 2-2.5\% dalam sambal-terasi adalah dicadangkan sebagai kompromi yang baik berkenaan dengan aspek sensori dan pengambilan garam.

Kata kunci: Analisis deria; garam; rasa; sambal-terasi; terasi

\section{INTRODUCTION}

Terasi is a salty paste of underutilized fish/seafood used in Indonesia, consisting mostly of planktonic shrimp, known as rebon. Throughout Asia, closely related products are well-known, such as belacan in Malaysia; kapi in Thailand and Cambodia; bagoong-alamang in Philippines; mam-ruoc or mam-tom in Vietnam; jeotgal/jeot in Korea; and ngapi-seinsa or hmyinnga-pi in Myanmar (Ruddle \&
Ishige 2010). These paste products not only differ largely as a result of variations in the raw material used and manufacturing practices (Damanik-Ambarita et al. 2019; Guan et al. 2011), but also vary due to the different amounts of salt added. Various reports indicate large variations in the amount of salt used during the production of fish or shrimp paste. For instance, 5-20\% (Hajeb \& Jinap 2012; Kleekayai et al. 2016), more than $30 \%$ of salt (Campbell- 
Platt 1987), while sometimes even no salt is added at all during the production of fish/shrimp pastes in some parts of Myanmar, Indonesia, Thailand, and The Philippines (Ruddle \& Ishige 2010). Consequently, both chemical characteristics and salt content among different shrimp pastes vary greatly. Typically, in terasi, salt is the second major ingredient used, apart from rebon or other aquatic animals.

Excessive salt intake is among others a risk factor for cardiovascular diseases, which is currently the main cause of death in Indonesia (World Health Organization 2018). Therefore, the Indonesian Ministry of Health formulated new dietary guidelines (Permenkes 2013 No 30) which includes the advice to limit the intake of salt $(2 \mathrm{~g}$ sodium per day or $5 \mathrm{~g}$ salt per day). However, in 2007, the average intake of salt among Indonesians was $5.6 \mathrm{~g}$ per capita per day, while in 2017 it has increased to $6.3 \mathrm{~g}$ per capita per day, resulting in a salt intake above the recommended levels by more than half of the population. Salt intake has been reported to originate mainly from non-labelled foods, eaten at home or out of home (Hardinsyah 2017). Interestingly, Choong et al. (2012) reported that the preferred consumption of dishes containing the high salt sodium shrimp paste belacan in Malaysia, seemed to discourage discretionary salt use. This implies that despite their high salt content, the addition of shrimp paste to foods could overall limit the salt intake. In Indonesia, terasi is typically used in chili sauce, known as sambal-terasi. Damanik-Ambarita et al. (2019) identified the sensory profiles of sambal-terasi made according to recipes from several restaurants. However, the authors found that the use of high amounts of terasi (12.5\% dry matter content, equal to about $17 \%$ fresh weight of terasi) and salt (5.6\%) to make sambalterasies, produced a too salty or too bitter sambal-terasies. Panelists were hardly able to identify other mild tastes/ flavors, therefore, the real impact of terasi and the sensory profile of sambal-terasi were considerably complex. Consequently, for this study, the amount of terasi was reduced to $6 \%$ fresh weight (and therefore also reducing their salt content) so that the key attributes of sambal-terasi could be better investigated. This study also evaluated the impact of different types of terasi (including salt content) on the sensory characteristics of sambal-terasi. The impact of the addition of salt on the sensory characteristics of sambal-terasi was also further studied.

\section{MATERIALS AND METHODS}

\section{TERASI SAMPLES}

Terasi samples were collected from six famous regions for terasi production or sambal-terasi consumption in Indonesia and were coded as A (from West Java), B (from Jakarta), C (from North Sumatera), D (from Central Java), E (from West Kalimantan), and F (from East Java). Terasi A, D, and F were taken from traditional factories. Terasi $\mathrm{D}$ and $\mathrm{F}$ contained salt and rebon; while terasi A was also composed of small fish, and rice bran. However, detailed compositional data were not shared by the producers, and/ or were unavailable. Meanwhile, terasi B, C, and E were taken from markets without specific information regarding the ingredients used nor the production process and date. Although the information is a great interest for this study, unfortunately, the producers considered these data as confidential and unable to share the information when the authors asked for further details. All samples were stored in a freezer $\left(-28 \pm 2^{\circ} \mathrm{C}\right)$ until they were further analyzed or used.

\section{CHEMICAL ANALYSES}

Terasi samples were analyzed in Indonesia in triplicate for their moisture, fat, protein, and carbohydrate content as described by Damanik-Ambarita et al. (2019). $\mathrm{NaCl}$ (salt) content, was measured indirectly by the determination of chloride ions by using the method as described by Damanik-Ambarita et al. (2019). The data was used to normalize the amount of salt added to sambal-terasi samples with salt addition. The total amount of salt was equal to the highest salt content amongst six sambalterasies (sambal-terasi A). At a later stage of the research, sambal-terasi samples were analyzed in Belgium for their sodium, calcium, magnesium, and potassium content by using inductively coupled plasma optical emission spectrometry, ICP-OES (Varian Vista MPX, Palo Alto, CA, USA), while phosphorous were measured by using the colorimetric method of Scheel. The methods of analyses have been described by Damanik-Ambarita et al. (2019). Free amino acids (FAAs), biogenic amines (BAs) and short chain fatty acids (SCFAs) were determined according to the method as described by Damanik-Ambarita et al. (2019).

\section{CHILI SAUCE AND SAMBAL-TERASI PREPARATION}

A base of chili sauce was prepared one time for all sambalterasies by using a standard recipe as described by Damanik-Ambarita et al. (2019), to avoid differences due to the chili sauce. The sauce contained fresh, minced and blended ingredients of Capsicum annuum, a large sweet and mild variety of chili, also known in Indonesia as Taiwanese-chili (25\%). Additional ingredients consisted of tomato (20\%); shallot (15\%); garlic (14\%); palm oil (9\%); onion (7\%); palm sugar (5\%); candle nut (3\%); ginger (1\%) and lemon grass (1\%) (all on fresh weight). Ingredients were bought from local supermarkets located near the laboratory of the Department of Food Technology, Universitas Pelita Harapan (UPH), Karawaci, Indonesia. To prepare the chili sauce, all ingredients were sautéed for approximately $45 \mathrm{~min}$ for a $12 \mathrm{~kg}$ of mixture. Terasi was heated (about $30 \mathrm{~s}$ ) until the aroma was released; and mixed (6\% fresh weight) and sautéed together with chili sauce (about $20 \mathrm{~min}$ for $1 \mathrm{~kg}$ of sauce). One set of six sambalterasies was prepared without salt adjustment. Salt content, based on chloride-determination in terasi, amounted for 
sambal-terasies A to F, respectively, 1.97, 0.71, 1.36, 0.62, $0.28,0.79 \mathrm{~g} / 100 \mathrm{~g}$ product. To another set of five sambalterasies (B-F), table salt was added aiming to have a final salt content of $1.97 \%$ (based on chloride determination; on fresh weight), representing the highest salt content among six sambal-terasies (sambal-terasi A). These samples were identified, respectively, as B+Salt; $\mathrm{C}+$ Salt; $\mathrm{D}+$ Salt; $\mathrm{E}+$ Salt and $\mathrm{F}+$ Salt. Therefore, in total 11 sambalterasies were prepared one day before the sensorial evaluation (overnight storage at $4{ }^{\circ} \mathrm{C}$ ). All samples were kept frozen $\left(-28 \pm 2{ }^{\circ} \mathrm{C}\right)$ before sending to Belgium for mineral analyses as previously explained.

QUANTITATIVE EVALUATION OF SELECTED TASTE/ FLAVOR ATTRIBUTES OF THE SAMBAL-TERASI'S BY A TRAINED PANEL

Eleven sambal-terasies were sensorially assessed by nine trained panelists ( 1 male and 8 females, age between 23 and 41 years) by considering the following taste/flavor attributes of sambal-terasies: salty, sour, sweet, bitter, umami, rebon and fishy. The trained panel was selected among 72 panelists (students and staffs at a Department of Food Technology) based upon $80 \%$ accuracy through a series of basic test identifications. Although the hotness of the sauce is by no doubt another important flavor attribute, it was not considered in the sensory trial in view of the relatively high number of other attributes already considered and because the hotness is evidently caused by the presence of similar amounts of chili sauce in the first place. This sensory evaluation was carried out with two replications on different days.

Panelists were trained six times during a two-hour session in a two weeks period, and conducted subsequent sensory analyses e.g. triangular tests, same different tests, and descriptive sensory analysis. They were taught and became familiar with the sensory vocabularies applied to rate chili sauces and sambal-terasies flavor attributes using $15-\mathrm{cm}$ unstructured line scales (0 meant no taste and 15 meant the highest or most extreme intensity of the respective taste which was agreed upon in the panel as explained next). For each of the sensory attributes the following reference materials were chosen to train the panel to carry out a quantitative sensory assessment for each attribute: sucrose (sweetness), $\mathrm{NaCl}$ (saltiness), vinegar containing $25 \%$ acetic acid (sourness), caffeine (bitterness), monosodium glutamate (umami), dried rebon (rebon), and dried anchovies (fishy). The reference materials were dissolved at various concentrations covering a particular range in chili sauce (after an initial training in water). The highest concentration for each reference material (the maximum of the scale (15)) was determined by evaluating various concentrations followed by a group discussion with the whole panel with respect to their expectancy vis à vis each particular taste or flavor attribute in sambal-terasi. For instance, for the rebon attribute, dried rebon was added to the chili sauce in a concentration range $(0-20 \%)$. The taste panel considered the sauce containing $20 \%$ rebon as the highest concentration corresponding to the maximum score of 15 in the unstructured line scale.

For all sensory trials, panelists were served individually with $10 \mathrm{~g}$ of each sambal-terasi sample on small red plates (diameter of $8 \mathrm{~cm}$ ), coded with a random three-digit number. They each tasted a $0.5-1 \mathrm{~g}$ sample of sambal-terasi using a tea spoon, in a sensory panel booth at $24{ }^{\circ} \mathrm{C}$ with red lighting to disguise the samples' appearance. All sambal-terasies were maintained at $24{ }^{\circ} \mathrm{C}$ as well. Plain crackers and water were consumed between samples to rinse the palate.

\section{HEDONIC SENSORY EVALUATION OF SAMBAL-TERASI'S BY AN UNTRAINED PANEL}

The eleven prepared sambal-terasies were also sensorially evaluated by a group of 87 panelists ( 69 females, 18 males; age of 17-41 years). Panelists were students and staff of UPH Karawaci and participated in similar tests with other foods before. They had no respiratory and fish or shrimp allergy and did not consume any food at least $30 \mathrm{~min}$ before sensory testing.

The panelists evaluated each individual sambal-terasi using a score ranging from 1 (dislike very much) to 7 (like very much). This resulted in an overall scoring for each sample. In addition for each sample they also evaluated particular taste attributes as mentioned using the same score. Finally, each panelist was asked in an open-end question to identify the samples which they liked/disliked the most. The procedures for the hedonic sensory tests were generally adapted from Meilgaard et al. (2006) and the International Organization for Standardization (ISO) 11136:2014 for hedonic test.

\section{DATA ANALYSIS}

Raw (non-normalized) sensory data were used. All statistics analyses were done by using SPSS 24 (IBM, New York, USA). The confident level was set at $5 \%$ for Analysis of Variance (ANOVA) and followed by Tukey's test to identify statistical differences among the samples for the set of sambal-terasi without salt addition. To test the effect of salt addition to the sambal-terasies; one-way ANOVA combined with planned contrast analysis was done to evaluate the sensory data with and without salt addition by either un-trained or trained panelists.

\section{RESULTS AND DISCUSSION}

\section{CHEMICAL CHARACTERISTICS OF TERASI SAMPLES} (TERASI A-F)

Tables 1-3 show the chemical characteristics of the terasi samples. The proximate composition, salt content and water activity were significantly different $(p<0.05)$ among the terasi samples (Table 1), which is not surprising as these terasies were taken from different provinces with variation in ingredient(s) and production processes. 
TABLE 1. Proximate composition, salt, and water activity $\left(\mathrm{a}_{\mathrm{w}}\right)$ of commercial products of terasi samples

\begin{tabular}{lccccccc}
\hline $\begin{array}{l}\text { Parameter } \\
\text { g/100g; on } \\
\text { fresh weight } \\
\text { (FW) }\end{array}$ & A & B & C & D & E & F & p-value \\
\hline Water content & $27.01 \pm 0.18 \mathrm{a}$ & $30.94 \pm 0.05 \mathrm{~b}$ & $32.23 \pm 0.33 \mathrm{c}$ & $27.46 \pm 0.24 \mathrm{a}$ & $37.41 \pm 0.49 \mathrm{e}$ & $35.16 \pm 0.14 \mathrm{~d}$ & $<0.001$ \\
Protein & $22.63 \pm 0.01 \mathrm{a}$ & $36.99 \pm 0.21 \mathrm{c}$ & $31.54 \pm 0.08 \mathrm{~b}$ & $42.83 \pm 0.39 \mathrm{f}$ & $41.56 \pm 0.48 \mathrm{e}$ & $38.74 \pm 0.02 \mathrm{~d}$ & $<0.001$ \\
Fat & $2.28 \pm 0.06 \mathrm{a}$ & $3.91 \pm 0.18 \mathrm{bc}$ & $2.19 \pm 0.49 \mathrm{a}$ & $4.46 \pm 0.46 \mathrm{c}$ & $3.55 \pm 0.11 \mathrm{~b}$ & $3.76 \pm 0.05 \mathrm{bc}$ & $<0.001$ \\
Ash & $43.42 \pm 0.05 \mathrm{f}$ & $24.72 \pm 0.16 \mathrm{~d}$ & $30.88 \pm 0.49 \mathrm{e}$ & $17.88 \pm 0.08 \mathrm{~b}$ & $11.93 \pm 0.20 \mathrm{a}$ & $19.11 \pm 0.24 \mathrm{c}$ & $<0.001$ \\
Carbohydrate & $4.66 \pm 0.07 \mathrm{bc}$ & $3.44 \pm 0.19 \mathrm{ab}$ & $3.15 \pm 0.56 \mathrm{a}$ & $7.37 \pm 1.17 \mathrm{~d}$ & $5.56 \pm 0.11 \mathrm{c}$ & $3.23 \pm 0.07 \mathrm{ab}$ & $<0.001$ \\
Salt & $32.83 \pm 0.23 \mathrm{f}$ & $11.76 \pm 0.02 \mathrm{c}$ & $22.74 \pm 0.19 \mathrm{e}$ & $10.28 \pm 0.01 \mathrm{~b}$ & $4.60 \pm 0.01 \mathrm{a}$ & $13.05 \pm 0.04 \mathrm{~d}$ & $<0.001$ \\
aw* at $20^{\circ} \mathrm{C}$ & $0.700 \pm 0.002 \mathrm{~d}$ & $0.671 \pm 0.003 \mathrm{~b}$ & $0.688 \pm 0.002 \mathrm{c}$ & $0.658 \pm 0.006 \mathrm{a}$ & $0.796 \pm 0.003 \mathrm{e}$ & $0.662 \pm 0.000 \mathrm{a}$ & $<0.001$ \\
\hline
\end{tabular}

All data are expressed as the mean $\pm \mathrm{SD}$ from three independent replications. Means with different letters are significantly different $(p<0.05)$ for each parameter (row); "no unit; Terasi A from West Java, B was from Jakarta, C was from North Sumatera, D was from Central Java, E was from West Kalimantan, and F was from East Java

Similarly, FAAs, BAs (especially putrescine and cadaverine) and SCFAs (such as propionic-, butyric- and isobutyric-, isovaleric-acid), that are major contributors to specific taste attributes and the (pungent) odor of fermented foods (Belitz et al. 2009), also differed significantly within the samples (Tables 2-3).

\section{SENSORY EVALUATION OF THE SAMBAL-TERASIES} WITHOUT SALT ADDITION (SAMBAL-TERASIES A-F)

Figure 1 shows that the sensory characteristics of the six different types of sambal-terasies (without extra salt added) as evaluated by the trained panelists, differed significantly $(p<0.05)$ on all intensities of taste/flavor attributes, except for sourness and sweetness. Therefore, these two attributes were not considered further.

Sambal-terasi A, having the highest salt content, also had the highest saltiness. While for all the other samples, the saltiness was not significantly different, despite substantial differences in their salt content. Sambal-terasi A had also the highest umami taste. Sambal-terasies C and $\mathrm{F}$ had also not significantly different in their umami intensities from sambal-terasi A. It should be noted however that umami taste of sambal-terasi $\mathrm{F}$ was not significantly different from sambal-terasi $\mathrm{B}$, which had the lowest umami taste. Sambal-terasi B also had the lowest fishy and rebon taste, while the other sambalterasies did not differ significantly from each other with respect to these attributes. Sambal-terasi E was clearly having an off-note in bitterness, while for the other samples, no differences in bitterness could be noted.

The trends observed in the quantitative sensory evaluation corresponded reasonably well with those observed in the hedonic test with the untrained panel (Table 4). Sambal-terasies A and C had the highest hedonic scores with respect to saltiness and umami. They also however had the highest scores for the rebon and fishy taste. Similarly, as for the quantitative evaluation, sambal-terasi E clearly had a deviating score with respect to bitterness, resulting in the lowest sensory appreciation for this attribute. Also sambal-terasies B and D however had a low appreciation with respect to their bitter notes. This resulted in a clear overall preference for sambal-terasies A and C, but sambal-terasi A was liked by most of the panelists. The lowest overall appreciation was observed for sambalterasi $\mathrm{E}$, which was however not statistically different compared to sambal-terasies B and D. Again however a clearly higher number of panelist indicated they disliked sambal-terasi $\mathrm{E}$, while the number of panelists disliking sambal-terasi $\mathrm{B}, \mathrm{D}$ and $\mathrm{F}$ was comparable.

Some patterns were seen that could potentially be linked between the chemical characteristics of terasies to the sensory characteristics of sambal-terasies. The bitterness increased by the increase of histamine $\left(\mathrm{R}^{2} 0.83\right)$, tryptamine $\left(\mathrm{R}^{2} 0.87\right)$, beta-phenylethylamine $\left(\mathrm{R}^{2} 0.64\right)$, isovaleric acid $\left(R^{2} 0.61\right)$, propionic acid $\left(R^{2} 0.64\right)$ and isobutyric acid $\left(R^{2} 0.60\right)$. These findings show that the undesirable compounds formed during the production of terasi could still be perceived when the terasi is incorporated into chili sauce. Thus, their presences should be controlled in terasi.

As the panelists were asked to explain which taste attribute contributed to their appreciation of the most liked/ disliked sample, insight in key taste attributes of sambalterasies could be obtained (Table 5). Considering sambalterasi A, with the highest overall hedonic score, it was obvious that its saltiness was a key element with respect to its sensory appreciation, followed by its umami and rebon flavor. Sambal-terasi C seemed to be appreciated as more equilibrated with respect to its saltiness, umami and rebon taste. The taste attributes bitterness and fishy were not or nearly not considered with respect to the sensory appreciation of these most preferred sambal-terasies.

Considering the least appreciated sambal-terasi $\mathrm{E}$, it became obvious its bitterness, already identified by the trained panel, was clearly a key factor. Also for the other less appreciated sambal-terasies B, D and F, bitterness was considered as the most relevant taste attribute.

As a preliminary conclusion, it could be stipulated that a sufficient saltiness of sambal-terasies is clearly a key sensory attribute, combined with an absence of a too strong bitterness and the presence of umami and rebon notes. 
TABLE 2. Free amino acids (FAAs) content and biogenic amines (BA) for each terasi sample ( $\mathrm{g} / 100 \mathrm{~g}$ dry matter)

\begin{tabular}{|c|c|c|c|c|c|c|c|c|}
\hline FAA & A & $\mathrm{B}$ & $\mathrm{C}$ & $\mathrm{D}$ & $\mathrm{E}$ & $\mathrm{F}$ & SEM* & $\mathrm{p}$-value \\
\hline Aspartic acid & 0.64 & 0.87 & 0.62 & 0.68 & 1.9 & 1.4 & 0.040 & $<0.001$ \\
\hline Glutamic acid & 1.0 & 1.3 & 1.2 & 2.6 & 3.4 & 6.0 & 0.114 & $<0.001$ \\
\hline Asparagine1 & $<\mathrm{LOD}$ & $<\mathrm{LOD}$ & 0.11 & $<\mathrm{LOD}$ & $<\mathrm{LOD}$ & $<\mathrm{LOD}$ & $<0.001$ & $<0.001$ \\
\hline Serine & 0.16 & 0.34 & 0.34 & 0.25 & 0.25 & 0.73 & 0.012 & $<0.001$ \\
\hline Glutamine1 & 0.01 & $<\mathrm{LOD}$ & 0.01 & 0.02 & 0.01 & 0.06 & 0.003 & $<0.001$ \\
\hline Histidine & 0.06 & 0.09 & 0.15 & 0.25 & 0.18 & 0.51 & 0.011 & $<0.001$ \\
\hline Glycine & 0.37 & 0.52 & 0.86 & 1.4 & 1.3 & 2.4 & 0.059 & $<0.001$ \\
\hline Threonine & 0.37 & 0.46 & 0.53 & 0.36 & 0.72 & 1.1 & 0.030 & $<0.001$ \\
\hline Citrulline & 0.70 & 0.59 & 0.51 & 1.4 & 1.4 & 3.0 & 0.065 & $<0.001$ \\
\hline Arginine & 0.04 & 0.24 & 1.0 & 0.11 & 0.26 & 0.28 & 0.017 & $<0.001$ \\
\hline Alanine & 0.96 & 1.8 & 2.2 & 2.2 & 2.5 & 4.1 & 0.106 & $<0.001$ \\
\hline Tyrosine & 0.36 & 0.35 & 0.63 & 0.52 & 1.2 & 1.2 & 0.065 & $<0.001$ \\
\hline Valine & 0.37 & 0.84 & 0.69 & 1.1 & 1.2 & 2.2 & 0.067 & $<0.001$ \\
\hline Methionine & 0.13 & 0.08 & 0.13 & 0.43 & 0.83 & 0.78 & 0.052 & $<0.001$ \\
\hline Tryptophan & 0.08 & 0.10 & 0.06 & 0.16 & 0.26 & 0.32 & 0.020 & $<0.001$ \\
\hline Phenylalanine & 0.22 & 0.33 & 0.54 & 0.86 & 0.95 & 1.6 & 0.037 & $<0.001$ \\
\hline Isoleucine & 0.17 & 0.58 & 0.63 & 1.0 & 1.4 & 1.9 & 0.045 & $<0.001$ \\
\hline Leucine & 0.28 & 1.0 & 1.2 & 2.0 & 2.7 & 4.2 & 0.089 & $<0.001$ \\
\hline Lysine & 0.64 & 0.91 & 1.3 & 1.7 & 2.0 & 3.5 & 0.065 & $<0.001$ \\
\hline Proline & 0.15 & 0.28 & 0.39 & 0.62 & 0.94 & 0.93 & 0.009 & $<0.001$ \\
\hline Tryptamine 1 & $<\mathrm{LOD}$ & 0.01 & 0.03 & 0.05 & 0.20 & 0.07 & 0.022 & 0.001 \\
\hline$\beta$-phenylethylamine & 0.04 & 0.19 & 0.26 & 0.48 & 1.00 & 0.28 & 0.067 & $<0.001$ \\
\hline Putrescine & 0.31 & 1.00 & 2.00 & 1.60 & 1.00 & 2.10 & 0.113 & $<0.001$ \\
\hline Cadaverine & 0.49 & 0.76 & 1.20 & 3.00 & 0.47 & 1.30 & 0.060 & $<0.001$ \\
\hline Histamine & 0.05 & 0.08 & 0.07 & 0.06 & 0.12 & 0.06 & 0.013 & 0.020 \\
\hline Tyramine & 0.10 & 0.19 & 0.47 & 1.80 & 0.85 & 1.10 & 0.066 & $<0.001$ \\
\hline
\end{tabular}

All values are means of two independent replicates; *SEM: Standard error of the mean

${ }^{1}$ LOD asparagine: $1.10 \times 10^{-4} \mathrm{~g} / 100 \mathrm{~g}$ terasi (fresh weight); LOD glutamine: $1.43 \times 10^{-4} \mathrm{~g} / 100 \mathrm{~g}$ terasi (fresh weight); LOD Tryptamine: $4 \times 10^{-4} \mathrm{~g} / 100 \mathrm{~g}$ terasi (fresh weight)

TABLE 3. Short chain fatty acids (SCFAs) content (g/100g dry mater) for each terasi sample

\begin{tabular}{lcccccccc}
\hline SCFA & $\mathrm{A}$ & $\mathrm{B}$ & $\mathrm{C}$ & $\mathrm{D}$ & $\mathrm{E}$ & $\mathrm{F}$ & SEM $^{*}$ & p-value \\
\hline Acetic acid & 0.63 & 0.87 & 0.80 & 1.1 & 1.4 & 1.5 & 0.119 & $<0.001$ \\
Propionic acid (PA) & 0.055 & 0.055 & 0.054 & 0.085 & 0.11 & 0.072 & 0.008 & $<0.001$ \\
Isobutyric acid (IBA)1 & 0.048 & 0.069 & 0.16 & $<$ LOD & 0.24 & 0.009 & 0.008 & $<0.001$ \\
Butyric acid (BA)1 & 0.13 & 0.063 & $<$ LOD & 0.013 & $<$ LOD & 0.018 & 0.008 & $<0.001$ \\
Isovaleric acid (IVA) & 0.17 & 0.28 & 0.44 & 0.051 & 0.64 & 0.11 & 0.016 & $<0.001$ \\
Total SCFAs & 1.0 & 1.3 & 1.4 & 1.2 & 2.3 & 1.7 & & \\
Sum PA+IBA+BA+IVA & 0.40 & 0.47 & 0.65 & 0.15 & 0.98 & 0.21 & & \\
\hline
\end{tabular}

All values are means of three independent replicates; * SEM: Standard error of the mean

LOD for Isobutyric Acid and Butyric Acid: $2 \times 10^{-4} \mathrm{~g} / 100 \mathrm{~g}$ terasi (fresh weight)

In view of the relatively high differences in salt content between the sambal-terasies and the observation that the most preferred samples contained in fact the highest salt content, it was hypothesized that by adding salt to the less preferred samples, the overall sensory appreciation of those samples could be improved. Therefore, table salt was added to each of the sambal-terasies with the aim to reach a salt content similar to that of the sambal-terasi A. As on the time of the experiments only the chloride content data of the samples were available, it was not surprising that some 


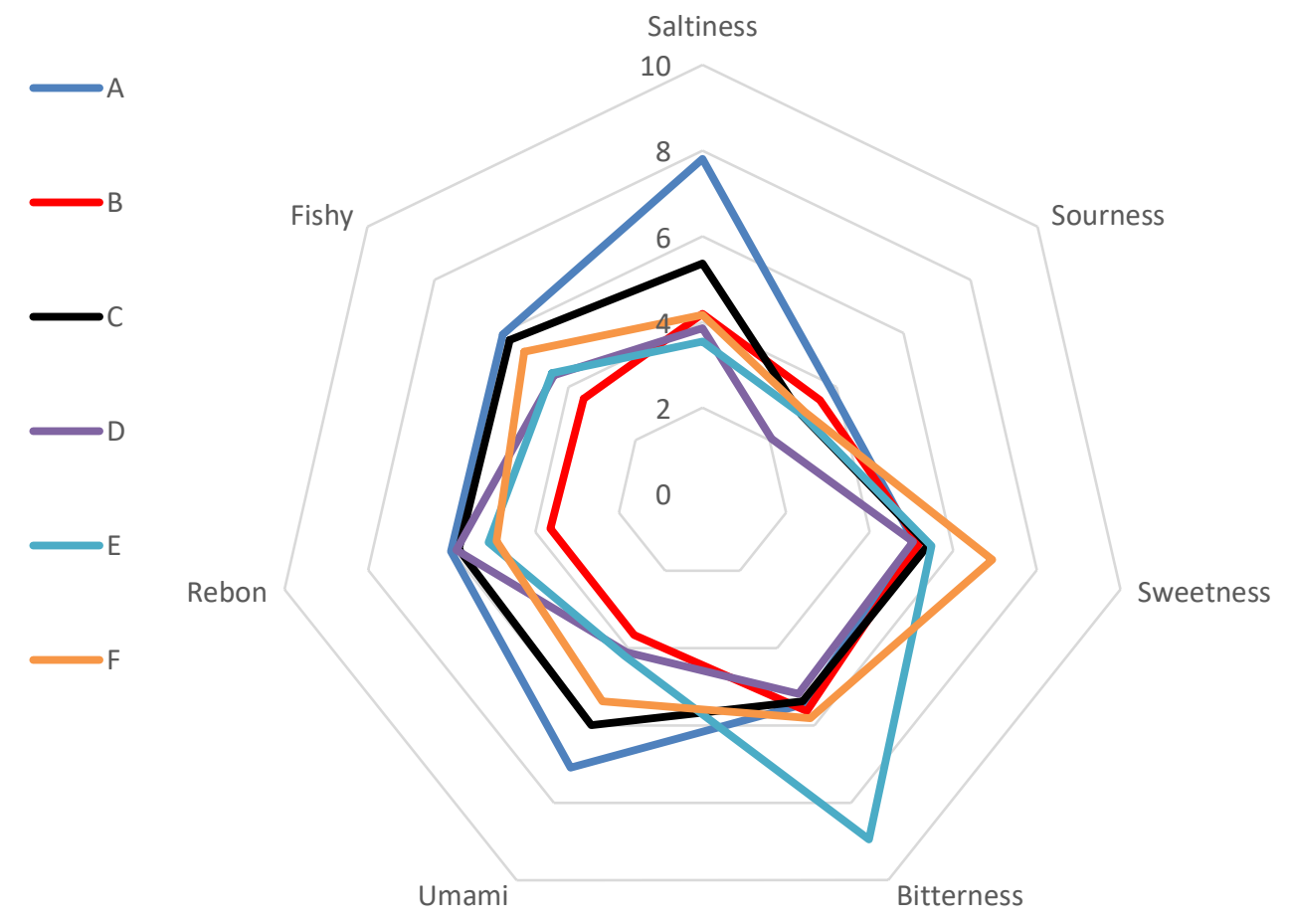

\begin{tabular}{lccccccc}
\hline Sample & Saltiness & Sourness & Sweetness & Bitterness & Umami & Rebon & Fishy \\
\hline A & $7.8 \pm 2.0^{\mathrm{b}}$ & $3.9 \pm 2.2^{\mathrm{a}}$ & $5.1 \pm 1.8^{\mathrm{a}}$ & $5.5 \pm 2.6^{\mathrm{a}}$ & $7.1 \pm 2.4^{\mathrm{c}}$ & $6.0 \pm 2.3^{\mathrm{b}}$ & $5.9 \pm 1.5^{\mathrm{b}}$ \\
$\mathrm{B}$ & $4.2 \pm 2.2^{\mathrm{a}}$ & $3.5 \pm 2.3^{\mathrm{a}}$ & $5.2 \pm 2.9^{\mathrm{a}}$ & $5.6 \pm 2.3^{\mathrm{a}}$ & $3.7 \pm 1.7^{\mathrm{a}}$ & $3.6 \pm 1.5^{\mathrm{a}}$ & $3.6 \pm 1.1^{\mathrm{a}}$ \\
C & $5.4 \pm 2.1^{\mathrm{a}}$ & $3.0 \pm 1.7^{\mathrm{a}}$ & $5.4 \pm 2.1^{\mathrm{a}}$ & $5.4 \pm 2.8^{\mathrm{a}}$ & $6.0 \pm 2.1^{\mathrm{bc}}$ & $5.8 \pm 1.6^{\mathrm{b}}$ & $5.7 \pm 2.0^{\mathrm{b}}$ \\
D & $3.9 \pm 1.9^{\mathrm{a}}$ & $2.1 \pm 1.6^{\mathrm{a}}$ & $5.0 \pm 2.9^{\mathrm{a}}$ & $5.2 \pm 2.7^{\mathrm{a}}$ & $4.1 \pm 2.1^{\mathrm{ab}}$ & $5.9 \pm 1.2^{\mathrm{b}}$ & $4.4 \pm 1.7^{\mathrm{ab}}$ \\
E & $3.5 \pm 2.3^{\mathrm{a}}$ & $3.0 \pm 1.6^{\mathrm{a}}$ & $5.5 \pm 3.0^{\mathrm{a}}$ & $8.9 \pm 2.8^{\mathrm{b}}$ & $4.2 \pm 2.5^{\mathrm{ab}}$ & $5.1 \pm 2.1^{\mathrm{ab}}$ & $4.5 \pm 1.9^{\mathrm{ab}}$ \\
F & $4.2 \pm 1.3^{\mathrm{a}}$ & $3.0 \pm 2.0^{\mathrm{a}}$ & $6.9 \pm 2.6^{\mathrm{a}}$ & $5.8 \pm 2.0^{\mathrm{a}}$ & $5.4 \pm 1.8^{\mathrm{abc}}$ & $4.9 \pm 2.2^{\mathrm{ab}}$ & $5.3 \pm 2.0^{\mathrm{b}}$ \\
SEM & 0.662 & 0.646 & 0.863 & 0.847 & 0.704 & 0.615 & 0.583 \\
$p$-value & $<0.001$ & 0.122 & 0.241 & $<0.001$ & $<0.001$ & 0.001 & $<0.001$ \\
\hline
\end{tabular}

Score 0 (absence of flavor) to 15 (maximum flavor perceived). All data are expressed as the mean \pm SD from 9 trained panelists. Means with different letters are significantly different $(p<0.05)$ for each parameter taste/flavour (column)

FIGURE 1. Mean perceived intensity of taste/flavor of six different sambal-terasies (spider diagram above) and its variability among treatments (table, below)

discrepancies between the salt content, based on the actual sodium content (as determined by ICP-OES) of the supplemented samples were observed (Table 6). Overall however, the goal of increasing the sodium content of sambal-terasies B-F towards the sodium content of sambal-terasi $A$ was achieved. It should also be realized that not only sodium ions are responsible for the salt taste, but that for instance also potassium, magnesium, calcium and phosphate ions may contribute as Li-Chan and Cheung (2010) had been noted. Moreover, potassium, magnesium, calcium, and phosphates can also act as salt replacer (Kilcast \& Ridder 2007; Liem et al. 2011; Manabe et al. 2009). However, these minerals may have differences in saltiness intensities in sea salts having similar amount of sodium (Vella et al. 2012) as these minerals have also other taste(s) or aftertaste. Although other chemical characteristics present in terasi may contribute to the differences in the sensory characteristics of sambal-terasi, former study (submitted paper) showed that there was no specific pattern to link the proximate compositions, free amino acids, and biogenic amines contents to the sensory characteristics of sambal-terasi.

\section{IMPACT OF TABLE SALT ADDITION TO THE SENSORY CHARACTERISTICS AND APPRECIATION OF SAMBAL- TERASIES}

Considering the data obtained by the trained panel (Figure 2 ), it is obvious that in all samples, the saltiness of all supplemented sambal-terasies significantly increased, which is not surprising. Similarly, the umami taste of all sambal-terasies increased, albeit for sambal-terasi $\mathrm{C}$ not significantly. The rebon flavor was the lowest for sambalterasi $\mathrm{B}$, while addition of salt increased its rebon flavor significantly, which was also observed in sambal-terasies 
TABLE 4. Average hedonic scores of the sambal-terasies obtained by an untrained panel and the planned contrast analysis result

\begin{tabular}{|c|c|c|c|c|c|c|c|c|c|c|}
\hline Sample & Saltiness & Sourness & Sweetness & Bitterness & Umami & Rebon & Fishy & Overall & $\Sigma$ Liked the most & $\Sigma$ Disliked the most \\
\hline A & $4.20 \pm 1.58 \mathrm{c}$ & $3.78 \pm 1.59 b$ & $3.72 \pm 1.44 \mathrm{~d}$ & $3.31 \pm 1.70 \mathrm{c}$ & $4.07 \pm 1.54 \mathrm{~d}$ & $4.00 \pm 1.45 b$ & $3.94 \pm 1.56 \mathrm{c}$ & $4.21 \pm 1.53 \mathrm{c}$ & 20 & 4 \\
\hline B & $2.60 \pm 1.28 \mathrm{ab}$ & $2.45 \pm 1.23 \mathrm{a}$ & $2.66 \pm 1.25 \mathrm{ab}$ & $1.86 \pm 1.00 \mathrm{ab}$ & $2.58 \pm 1.17 \mathrm{a}$ & $2.74 \pm 1.17 \mathrm{a}$ & $2.66 \pm 1.22 \mathrm{a}$ & $2.65 \pm 1.16 \mathrm{ab}$ & 2 & 11 \\
\hline $\mathrm{C}$ & $3.78 \pm 1.47 \mathrm{c}$ & $3.56 \pm 1.50 \mathrm{~b}$ & $3.33 \pm 1.42 \mathrm{~cd}$ & $2.98 \pm 1.63 \mathrm{c}$ & $3.73 \pm 1.37 \mathrm{~cd}$ & $3.81 \pm 1.34 \mathrm{~b}$ & $3.62 \pm 1.49 b c$ & $4.01 \pm 1.39 \mathrm{c}$ & 11 & 0 \\
\hline $\mathrm{D}$ & $2.52 \pm 1.41 \mathrm{ab}$ & $2.55 \pm 1.35 \mathrm{a}$ & $2.41 \pm 1.30 \mathrm{ab}$ & $2.21 \pm 1.56 \mathrm{ab}$ & $2.87 \pm 1.45 \mathrm{ab}$ & $2.92 \pm 1.36 \mathrm{a}$ & $2.99 \pm 1.47 \mathrm{a}$ & $2.73 \pm 1.38 \mathrm{ab}$ & 0 & 14 \\
\hline $\mathrm{E}$ & $2.11 \pm 1.22 \mathrm{a}$ & $2.29 \pm 1.37 \mathrm{a}$ & $2.12 \pm 1.18 \mathrm{a}$ & $1.67 \pm 0.99 \mathrm{a}$ & $2.48 \pm 1.29 \mathrm{a}$ & $2.82 \pm 1.50 \mathrm{a}$ & $2.84 \pm 1.45 \mathrm{a}$ & $2.28 \pm 1.40 \mathrm{a}$ & 3 & 34 \\
\hline $\mathrm{F}$ & $3.05 \pm 1.51 \mathrm{~b}$ & $2.76 \pm 1.31 \mathrm{a}$ & $2.91 \pm 1.35 b c$ & $2.33 \pm 1.32 b$ & $3.20 \pm 1.50 \mathrm{bc}$ & $3.07 \pm 1.37 \mathrm{a}$ & $3.01 \pm 1.39 \mathrm{ab}$ & $3.02 \pm 1.35 b$ & 3 & 13 \\
\hline p-value1 & $<0.001$ & $<0.001$ & $<0.001$ & $<0.001$ & $<0.001$ & $<0.001$ & $<0.001$ & $<0.001$ & - & - \\
\hline B+Salt & $3.94 \pm 1.54^{*}$ & $3.62 \pm 1.50^{*}$ & $3.81 \pm 1.44^{*}$ & $3.14 \pm 1.61^{*}$ & $4.01 \pm 1.52^{*}$ & $3.78 \pm 1.48^{*}$ & $3.66 \pm 1.46^{*}$ & $4.26 \pm 1.35^{*}$ & 9 & 1 \\
\hline $\mathrm{C}+$ Salt & $3.92 \pm 1.55$ & $3.38 \pm 1.46$ & $3.67 \pm 1.41$ & $3.06 \pm 1.73$ & $3.98 \pm 1.41$ & $3.88 \pm 1.43$ & $3.72 \pm 1.55$ & $4.12 \pm 1.47$ & 10 & 5 \\
\hline $\mathrm{D}+$ Salt & $3.69 \pm 1.64^{*}$ & $3.56 \pm 1.56^{*}$ & $3.54 \pm 1.52^{*}$ & $2.95 \pm 1.65^{*}$ & $3.94 \pm 1.49^{*}$ & $3.71 \pm 1.45^{*}$ & $3.47 \pm 1.42 *$ & $4.04 \pm 1.43^{*}$ & 5 & 1 \\
\hline E+Salt & $4.16 \pm 1.52 *$ & $3.54 \pm 1.62 *$ & $3.54 \pm 1.60^{*}$ & $3.09 \pm 1.72 *$ & $3.95 \pm 1.54^{*}$ & $3.81 \pm 1.51^{*}$ & $3.59 \pm 1.53^{*}$ & $4.12 \pm 1.48^{*}$ & 11 & 4 \\
\hline $\mathrm{F}+$ Salt & $4.12 \pm 1.65^{*}$ & $3.35 \pm 1.52 *$ & $3.62 \pm 1.41 *$ & $2.85 \pm 1.62 *$ & $3.98 \pm 1.57^{*}$ & $3.84 \pm 1.40^{*}$ & $3.48 \pm 1.54^{*}$ & $4.23 \pm 1.33^{*}$ & 13 & 0 \\
\hline
\end{tabular}

Hedonic score: 1 (dislike very much); 2 (dislike moderately); 3 (dislike slightly); 4 (neutral, neither dislike nor like); 5 (like slightly); 6 (like moderately); 7 (like very much); An overall score was given for each sample and for each sample the selected taste attribute was evaluated as well using the same scoring scale; All data are expressed as the mean \pm SD from 87 panelists; ' ${ }^{1}$ for sambal-terasies without salt addition; * *ignificance of planned contrast analysis are at p-value $<0.05$, comparing each sambalterasi without vs with salt addition to a final salt content of $1.97 \%$ 
TABLE 5. Reasons of panelists liking and disliking of sambal-terasies, with (+Salt) and without salt addition (to a final salt content of $1.97 \%$ )*

\begin{tabular}{|c|c|c|c|c|c|c|c|c|}
\hline Sambal-terasi & Total of responses & Saltiness & Sourness & Sweetness & Bitterness & Umami & Rebon & Fishy \\
\hline \multicolumn{9}{|c|}{ Number of panellists identifying the particular taste/flavor attribute as decisive in their sensory appreciation (liking) } \\
\hline A & 33 & 16 & 1 & 4 & 0 & 6 & 5 & 1 \\
\hline B & 6 & 2 & 0 & 2 & 0 & 2 & 0 & 0 \\
\hline $\mathrm{C}$ & 20 & 5 & 1 & 3 & 0 & 6 & 5 & 0 \\
\hline $\mathrm{D}$ & 0 & 0 & 0 & 0 & 0 & 0 & 0 & 0 \\
\hline $\mathrm{E}$ & 3 & 0 & 0 & 0 & 0 & 1 & 2 & 0 \\
\hline $\mathrm{F}$ & 3 & 0 & 0 & 2 & 0 & 1 & 0 & 0 \\
\hline $\mathrm{B}+$ Salt & 19 & 9 & 0 & 4 & 0 & 4 & 2 & 0 \\
\hline $\mathrm{C}+\mathrm{Salt}$ & 18 & 7 & 1 & 2 & 0 & 5 & 3 & 0 \\
\hline $\mathrm{D}+$ Salt & 8 & 2 & 1 & 1 & 0 & 1 & 2 & 1 \\
\hline $\mathrm{E}+$ Salt & 19 & 6 & 2 & 2 & 0 & 5 & 3 & 1 \\
\hline $\mathrm{F}+$ Salt & 25 & 10 & 0 & 3 & 0 & 8 & 4 & 0 \\
\hline
\end{tabular}

Number of panellists identifying the particular taste/flavor attribute as decisive in their sensory appreciation (disliking)

\begin{tabular}{lcccccccc} 
A & 6 & 0 & 1 & 0 & 4 & 0 & 0 & 1 \\
B & 19 & 1 & 1 & 2 & 11 & 2 & 1 & 1 \\
C & 0 & 0 & 0 & 0 & 0 & 0 & 0 & 0 \\
D & 23 & 0 & 4 & 2 & 14 & 0 & 0 & 3 \\
E & 49 & 6 & 3 & 2 & 32 & 2 & 0 & 4 \\
F & 17 & 0 & 1 & 3 & 11 & 1 & 1 & 0 \\
B+Salt & 2 & 1 & 0 & 0 & 1 & 0 & 0 & 0 \\
C+Salt & 7 & 0 & 0 & 0 & 5 & 1 & 0 & 1 \\
D+Salt & 2 & 0 & 0 & 0 & 1 & 0 & 0 & 1 \\
E+Salt & 7 & 1 & 1 & 1 & 2 & 1 & 0 & 1 \\
F+Salt & 0 & 0 & 0 & 0 & 0 & 0 & 0 & 0 \\
\hline
\end{tabular}

*Each panelist could give more than one taste/flavor attributes; ${ }^{1}$ terasi was generally defined as fishy and rebon flavor according to panelists

TABLE 6. Calcium, magnesium, sodium, potassium, phosphor and salt content of sambal-terasi with (+Salt) and without salt addition

\begin{tabular}{|c|c|c|c|c|c|c|c|}
\hline Sambal-terasi & Dry matter (g/100g FW) & Calcium* & Magnesium* & Sodium* & Potassium* & Phosphor* & Salt** \\
\hline A & 33.80 & 5.90 & 1.57 & 30.80 & 14.10 & 4.23 & 2.65 \\
\hline B & 31.90 & 4.86 & 1.55 & 7.20 & 14.90 & 4.62 & 0.58 \\
\hline $\mathrm{C}$ & 33.50 & 3.48 & 1.50 & 20.70 & 13.90 & 4.06 & 1.76 \\
\hline $\mathrm{D}$ & 33.50 & 5.01 & 1.50 & 6.90 & 14.20 & 4.54 & 0.59 \\
\hline $\mathrm{E}$ & 33.90 & 5.36 & 1.51 & 2.90 & 14.50 & 4.72 & 0.25 \\
\hline $\mathrm{F}$ & 34.10 & 4.76 & 1.42 & 8.90 & 14.40 & 4.41 & 0.77 \\
\hline $\mathrm{B}+\mathrm{Salt}$ & 34.50 & 4.57 & 1.41 & 27.20 & 13.90 & 4.18 & 2.39 \\
\hline $\mathrm{C}+$ Salt & 33.90 & 3.65 & 1.41 & 24.80 & 13.60 & 3.98 & 2.14 \\
\hline $\mathrm{D}+$ Salt & 32.70 & 4.63 & 1.50 & 21.10 & 14.10 & 4.44 & 1.75 \\
\hline $\mathrm{E}+$ Salt & 34.90 & 4.86 & 1.45 & 24.60 & 14.50 & 4.29 & 2.18 \\
\hline $\mathrm{F}+$ Salt & 34.60 & 4.51 & 1.40 & 24.20 & 14.50 & 4.20 & 2.13 \\
\hline SEM & - & 0.110 & 0.027 & 0.409 & 0.212 & 0.079 & - \\
\hline
\end{tabular}

Note: * in $\mathrm{mg} / \mathrm{g}$ dry matter sambal-terasi samples, all data are the mean of twice replications; ** in $\mathrm{g} / 100 \mathrm{~g}$ fresh weight sambal-terasi samples, calculated based on sodium content; SEM: standard error of mean 

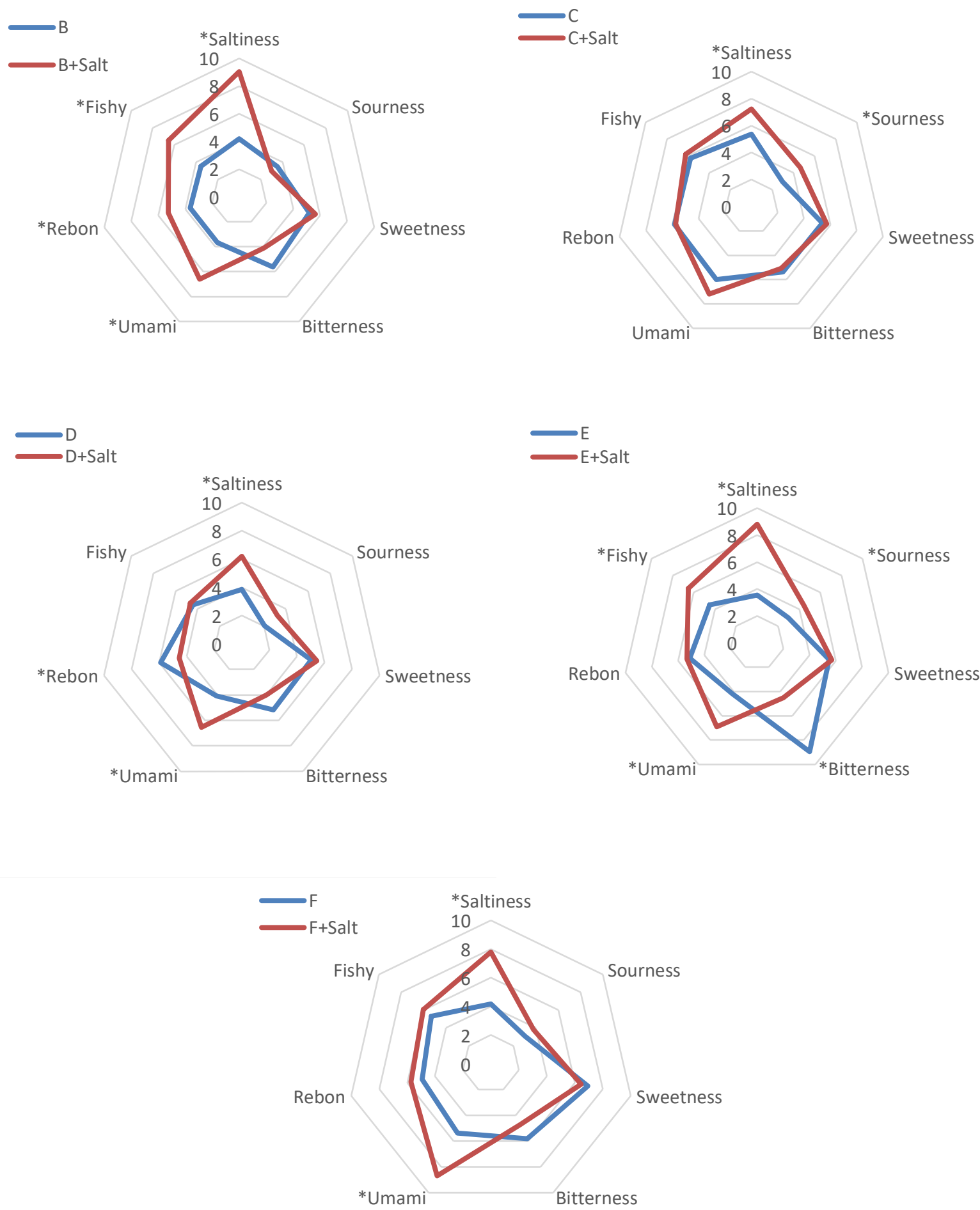

Score 0 (absence of flavor) to 15 (maximum flavor perceived). All data are expressed as the mean \pm SD from 9 trained panelists. $*$ representing the significant planned contrast-test $(\mathrm{p}<0.05)$

FIGURE 2. Comparison between the addition of salt (+Salt) and the original sambal-terasi of five different sambal-terasies 
D. Thus, it seems that increasing the salt content can improve key taste attributes which were identified to contribute positively to the overall sensory appreciation of sambal-terasies. In parallel, also the bitterness of sambal-terasies was reduced, in particular and significantly for the least appreciated sambal-terasi E. Previously, Keast and Breslin (2002) reported on the impact of various sodium salts on the reduced bitterness of a number of compounds. Similarly, Henney et al. (2010) reported on the suppression of bitterness by sodium.

Apart from boosting the desirable taste characteristics of sambal-terasies, a moderate increase of their salt content will also result in a softening of the bitter notes if present in the original terasi. In addition, it was shown via a contrast test, that all supplemented sambal-terasies were not appreciated different compared to sambal-terasi A ( $\mathrm{p}$ $>0.05$ for all sensory attributes).

Again the trends observed in the quantitative sensory evaluation by the trained panel were confirmed by the outcome of the hedonic sensory evaluation by the untrained panel. The overall hedonic scores for all supplemented samples, except sambal-terasi $\mathrm{C}+\mathrm{Salt}$, increased significantly compared to their original equivalents (Table 4). Similarly, all the scores for the considered taste attributes improved significantly for the supplemented sambal-terasies B-F+Salt. Comparing all supplemented sambal-terasies with sambal-terasi A via a planned contrast analysis, no significant differences could be found $(\mathrm{p}<0.05)$. For all salt supplemented samples, except sambal-terasi $\mathrm{C}$, an improved sensory appreciation could be noticed. One of the reasons for this is due to the amount of sodium ( $20 \mathrm{mg} / 100 \mathrm{~g}$ of sambal-terasi $\mathrm{C}$, Table 6$)$ that gives the saltiness and umami in sambal-terasi $\mathrm{C}$ could already be sufficient to provide the acceptance levels needed by panelists. Therefore, there were no significant changes occurred compared to the salt supplemented sambal-terasi C. Also, all sensory attributes of sambalterasi $\mathrm{C}$ were considerably balanced. The acceptability levels of all the key attributes that panelists appreciated (saltiness, umami, rebon) and did not appreciate (fishy and bitterness) in sambal-terasi $\mathrm{C}$ were insignificant as those of sambal-terasi A and all other salt-supplemented sambalterasies. Sodium plays a role in enhancing the palatability of food flavor, which also provides an overall balance among all sensory attributes of foods (Henney et al. 2010). For the supplemented samples only sambal-terasi $\mathrm{D}+$ Salt was appreciated by a rather limited number of panelists. Interestingly, it was noticed that its salt content was the only one below $2 \mathrm{~g} / 100 \mathrm{~g}$ (on fresh weight basis, based on sodium determination). Although this is a conclusion which in a larger scale study should be confirmed, it seems to suggest that a salt content of 2-2.5 g (based on sodium content) could be considered as a good compromise to achieve an equilibrated sensory appreciation of sambalterasies without avoiding excessive salt intake. As previously mentioned in the introduction section, in Indonesia, the salt intake is above the recommended level of WHO, and chili sauce (including sambal-terasi) was considered as one of the predominant sources of salt intake (Hardinsyah 2017). The findings of our study could improve the manufacturing practices on how to use appropriately salt and terasi in the production of sambalterasi. Thus, salt is only added if necessary (when the salt content of sambal-terasi is $<2-2.5 \mathrm{~g} / 100 \mathrm{~g}$ ). When excessive salt is added (e.g. salt content $>2.5 \mathrm{~g} / 100 \mathrm{~g}$ ), there are tendencies to add sugar, monosodium glutamate, or other types of flavor enhancers to balance the overpower tastes/flavors of sambal-terasi (Damanik-Ambarita et al. 2019). This practice, unfortunately, will cause problem in overuse of sodium, sugar and other food additives. Although no data could be found with respect to the sensory threshold or preference levels with respect to the salt content in chili sauces or sambal-terasi, it seems reasonable to speculate that by the addition of terasi to the chili sauces, the salt content of the sambal-terasi can be kept lower compared to the chili sauces without terasi. Peptides (Ohta et al. 2005) or amino acids such as sodium aspartate (Nakagawa et al. 2014) are known to enhance the salty taste. In addition, odorous compounds could also improve salty taste perception as proven for sardine aroma (Lawrence et al. 2011) or as documented for another fermented product such as soy sauce (Chokumnoyporn et al. 2015). In view of the nature of terasi and its production, it is obvious that there are a variety of compounds present in terasi which potentially will enhance the salty taste of products in which it is used. Apart from its sodium content, other compounds present in terasi can have an impact on the salty perception of sambal-terasi.

\section{CONCLUSION}

The addition of terasi to chili sauce is a common practice in Indonesia in order to create a desirable salty, umami and rebon tastes/flavor, the key attributes in sambal-terasi. The addition of different types of terasies significantly changed the sensory characteristics of sambal-terasies. The undesirable compounds formed during production of terasi (biogenic amines and short chain fatty acids) could still be perceived in sambal-terasi, therefore their presences should be controlled. A sufficient amount of salt (2.0-2.5 $\%$ of total weight) is necessary to reduce the bitterness and to enhance the desirable taste/flavor attributes.

\section{ACKNOWLEDGEMENTS}

The authors thank the Directorate General of Higher Education, Ministry of Education, Republic of Indonesia for the funding and all panelists for the sensory evaluations.

\section{REFERENCES}

Campbell-Platt, G. 1987. Fermented Foods of the World. A Dictionary and Guide. Cambridge, UK: Buttersworth.

Chokumnoyporn, N., Sriwattana, S., Phimolsiripol, Y., Torrico, D.D. \& Prinyawiwatkul, W. 2015. Soy sauce odour induces and enhances saltiness perception. International Journal of Food Science and Technology 50: 2215-2221. 
Choong, S.S.Y., Balan, S.N., Chua, L.S. \& Say, Y.H. 2012. Preference and intake frequency of high sodium foods and dishes and their correlations with anthropometric measurements among Malaysian subjects. Nutrition Research and Practice 6: 238-245.

Damanik-Ambarita, M.T., Raes, K. \& De-Meulenaer, B. 2019. The sensory acceptance and profile of Indonesian sambal-terasi: Impact of terasi type and concentration. International Journal of Gastronomy and Food Science 16: 100149 .

Guan, L., Cho, K.H. \& Lee, J.H. 2011. Analysis of the cultivable bacterial community in jeotgal, a Korean salted and fermented seafood, and identification of its dominant bacteria. Food Microbiology 28: 101-113.

Hajeb, P. \& Jinap, S. 2012. Fermented shrimp products as source of umami in Southeast Asia. Journal of Nutrition \& Food Science S10-006. DOI:10.4172/2155-9600.S10006.

Hardinsyah, R. 2017. Current intake of salt and its regulations in Indonesia. Annals of Nutrition and Metabolism 71: 39.

Henney, J.E., Taylor, C.L. \& Boon, C.S. 2010. Strategies to reduce sodium intake in the United State. Advances in Nutrition 1(1): 49-50.

Keast, R.S.J. \& Breslin, P.A.S. 2002. An overview of binary taste-taste interactions. Food Quality and Preference 14: 111-124.

Kilcast, D. \& den Ridder, C. 2007. Sensory issues in reducing salt in food products. In Reducing Salt in Food, Practical Strategies, edited by Kilcast, D. \& Angus, F. Cambridge, England: CRC, Woodhead Publishing in Food Science, Technology and Nutrition.

Kleekayai, T., Pinitklang, S., Laohakunjit, N. \& Suntornsuk, W. 2016. Volatile components and sensory characteristics of Thai traditional fermented shrimp pastes during fermentation periods. Journal of Food Science and Technology 53: 13991410.

Lawrence, G., Salles, C., Palicki, O., Septier, C. \& Busch, J. 2011. Using cross-modal interactions to counterbalance salt reduction in solid foods. International Dairy Journal 21: 103-110.

Li-Chan, E.C.Y. \& Cheung, W.Y. 2010. Flavor-Active properties of amino acids, peptides, and proteins In Bioactive Proteins and Peptides as Functional Foods and Nutraceuticals, edited by Mine, Y., Li-Chan, E. \& Jiang, B. Blackwell Publishing Ltd. and Institute of Food Technologists. pp. 341-358.

Liem, D.G., Miremadi, F. \& Keast, R.S.J. 2011. Reducing sodium in foods: The effect on flavor. Nutrients 3: 694-711.
Manabe, M., Ishizaki, S., Yoshioka, T. \& Oginome, N. 2009. Improving the palatability of salt-reduced food using dried bonito stock. Journal of Food Science: Sensory and Food Quality 74: S315-S321.

Meilgaard, M.C., Carr, T. \& Civille, G.V. 2006. Sensory Evaluation Techniques. 4th ed. Boca Raton: CRC Press.

Nakagawa, T., Kohori, J., Koike, S., Katsuragi, Y. \& Shoji, T. 2014. Sodium aspartate as a specific enhancer of salty taste perception-sodium aspartate is a possible candidate to decrease excessive intake of dietary salt. Chemical Senses 39: 781-786.

Ohta, S., Saitoh, C., Iwasaki, H., Morita, A. \& Kyowa Hakko Kogyo Co. Ltd. assignee. 2005. Method of Enhancing Salty Taste, Salty Taste Enhancer, Salty Taste Seasoning Agent and Salty Taste-Enhanced Foods. US Patent 6974597 B2.

Ruddle, K. \& Ishigei, N. 2010. On the origins, diffusion and cultural context of fermented fish Products in Southeast Asia. In Globalization, Food and Social Identities in the Asia Pacific Region, edited by Farrer, J. Sophia. Tokyo: University Institute of Comparative Culture.

Vella, D., Marcone, M. \& Duizer, L.M. 2012. Physical and sensory properties of regional sea salts. Food Research International 45: 415-421.

World Health Organization. 2018. Noncommunicable Diseases Country Profiles: Indonesia. https://www.who.int/nmh/ countries/idn_en.pdf.

Mery Tambaria Damanik Ambarita*, Katleen Raes \& Bruno De Meulenaer

Department of Food Technology

Safety and Health, Member of Food2Know

Faculty of Bioscience Engineering

Ghent University, Ghent-9000

Belgium

Mery Tambaria Damanik Ambarita*

Food Technology Department

Faculty of Science and Technology

Universitas Pelita Harapan

Indonesia

*Corresponding author; email: Mery.DamanikAmbarita@ Ugent.be

Received: 25 July 2019

Accepted: 29 November 2019 
